\title{
The Evaluation of Music Teacher Candidates' Awareness of Music Applications and Software, Their Frequency of Use and Purpose of Use
}

\author{
Emrah Lehimler \\ Correspondence: Emrah Lehimler, Fine Arts Faculty, Atatürk University, Erzurum, Turkey. \\ Received: July 11, 2019 \\ doi:10.11114/jets.v7i10.4381 \\ Accepted: August 18, 2019 Online Published: August 22, 2019 \\ URL: https://doi.org/10.11114/jets.v7i10.4381
}

\begin{abstract}
The purpose of the study is to examine the music teacher candidates' awareness of music applications and software, their frequency of use and purpose of use in terms of gender and grade level variables. The study group consists of 452 students studying in department of music education in 6 universities in Turkey during the 2018-2019 academic year. In order to collect data, a two-part questionnaire developed by the researcher was used.

According to the results of the research, it was seen that music teacher candidates who are aware of the existence of applications for music notation, applications containing instruments for music performance, applications for listening/watching music and applications for recording/mixing stage were quite high compared to those who were not aware. It was observed that the number of those who were not aware of the applications of instrument education, applications of choir/singing and applications of music theory and hearing education were higher than those who were aware. It was seen that the most commonly used applications were applications that include instruments for music performance and applications for listening/watching music. It was seen that applications for choir/singing, applications for instrument education, applications for music theory and hearing education, and applications for recording/mixing stage were rarely used.
\end{abstract}

According to the results obtained from the research, applications for music theory and hearing education, applications for instrument education and applications that include instruments for music performance were mostly used for professional development. It was found that applications for writing notes were mostly used for homework. Applications for listening/watching music, recording / mixing stage and chorus/singing applications were mostly used for entertainment purposes.

The results of the study showed that music teacher candidates were less familiar with applications and software especially for the performance aspect of music. According to the results, it can be said that music teacher candidates do not know music applications and software adequately.

Keywords: music application, music software, music education

\section{Introduction}

As a common result of production and consumption, technological progress has accelerated and gained momentum in terms of its usage in all segments of society and in all aspects of life. According to Turan et al. (2016), technology is becoming more and more popular in a wide range of life from business to health, from entertainment to education, and transforming people into digital citizens. Aksoy (2003) emphasized the need to review technology according to the organization and functioning of educational institutions, the method used in the educational process, and the content of education and, its effect on social sphere through education. As a result of the studies, it has become possible to use new methods and techniques in the learning process with technological tools and thus many innovations and arrangements have been made in the regulation of learning environments (Usta \& Korkmaz, 2010). In order to implement the regulations in education, teacher candidates are expected to follow the technological developments and changes. In other words, common and effective use of next generation information and communication technologies plays a key role in teacher education (Yükseltürk \& Top, 2016).

Technology, as in all other fields, is increasing its influence in the field of music. Technological tools (computers, tablets, smart phones, etc.) that make it easier to access all aspects of music have changed our habits of creating, listening, singing, playing and perceiving music. Although the products produced in terms of music are essentially the same as the old ones, the changes in the tools and methods used have created differences in the stages of music 
production, performance, recording, distribution and education.

The first educational music software was created on very large mainframes as a result of research conducted in universities in the period from the late 1960s to the early 1970s (Peters, 1992). Music software developed especially after the 70s shaped the way people compose music and make music. In particular, the invention of microphones, magnetic tapes, amplifiers and computers led to the creation of new styles of music in the 20th century (Toro, 2018). Reese and Rimington (2000) argue that technology education given to music educators should be focused on music technologies when developing and changing music technologies are taken into consideration. According to Roblyer and Edwards (2000), some music educators' attitude towards using computers and other educational tools is not positive. However, technology is a powerful tool that develops traditional teaching and music creation methods in the classroom. Computer technology can improve the musical experiences of students with special needs and enable them to respond to individual learning needs. This can also contribute to self-esteem because students create music that promptly encourages positive feedback (McCord, 2001). Students have different interests and learning styles when choosing the appropriate curriculum and course materials for studying music. Enthusiastic musicians can develop musical art and personal expression in addition to their musical skills and knowledge (Axford, 2015). This will help music educators design technological environments that will help them develop musical intelligence through intelligent selection of curriculum content, conducting events, selecting appropriate technologies, and supporting a culture of creativity (Brown, 2012).

Today, especially when mobile technologies are considered, it is easier to access and use music applications and software. Compared to the educational music software programs that were used once, mobile music applications are much more cost-effective and accessible (Purves, 2018). The integration of music technologies to mobile systems today has turned music production and education into a more accessible and more economical form. It is now much easier and cheaper to produce music for every individual with a mobile phone and tablet. The ability to use applications online can enable the sharing of information among users and create an interactive music education environment.

In accordance with traditional teaching methods, the continuation of music education in terms of knowledge and technique (master-apprentice) learned from the teacher makes technology integration difficult. The fact that the educational technological tools created for the application dimensions of music such as playing and singing is not known or preferred by trainers makes the use of technology in music education even more difficult. In this respect, it is essential to ensure that music teachers have the necessary equipment to integrate musical technologies into their courses. To use music applications and software correctly, it is important to know the features of each software and hardware tool. With these insights, a music teacher will be able to choose the right tools for education and maximize the musical potential of the students.

The field of music technologies is now one of the skills of the music teaching profession. Music teachers should develop their skills in using mobile music technologies in particular and integrate these technologies into the structure of the course. It is important to know how much music teacher candidates are familiar with musical technologies and to determine the usage amount of applications and software produced especially for mobile systems.

In this context, the aim of the study is to examine the music teacher candidates' awareness of music applications and software, their frequency of use and purpose of use in terms of gender and grade variables.

For this purpose, answers to the following questions were sought:

1. What is the status of music teacher candidates' awareness of music applications and software?

i. Does music teacher candidates' awareness of applications and software differ according to gender and grade

ii. ?

2. What is the frequency of music teacher candidates using music applications and software?

iii. Does the frequency of music teacher candidates use of music applications and software differ according to gender and present grade level in course?

3. What are the purposes of music teacher candidates when using the music applications and software?

\section{Method}

This research is a descriptive study carried out in screening model. In this direction, it was aimed to determine whether music teacher candidates were aware of music applications and software, their frequency of use and purpose of use and whether they differ according to gender and present grade level in course variables.

Music applications and software examined in the research were divided into 7 categories:

- Applications and Software for Music Theory and Hearing Education: Applications and software for music theory and hearing education are applications and software that include topics such as harmony, range, series, 
chords, melody creation, dictation, note reading, ear training. These software include the theoretical part of music as well as ear training elements and can work online or offline. Some applications create hearing, harmony, or theory classes and allow students to communicate with each other and with teachers. Ear Master, Tenuto, Complete Ear Trainer, Clef Tutor, Pro Chords are examples of software and applications in this area.

- Applications and Software for Music Notation: Applications and software for music notation cover the music notation topics. These softwares are mainly for writing and editing notes, but also include titles such as harmonization and transposing. Some music notation applications can recognize the notes printed in pdf or paper and convert them to digital version and convert music with sound files into notes. Examples of software and applications in this area are Finale, Sibelius, Muse Score, Muse2, Staff Pad, Notation Pad, Pia Score, Score Creator.

- Applications and Software for Recording/Mixing Stage: Applications and software for recording and mixing are the ones that include topics such as recording music, processing audio, microphoneing, and editing audio. This software includes music recording and audio editing as well as smart harmony and note writing. Examples of software and applications in this area are Garage Band, Cubase, Logic Pro, Adobe Audition, Pro Tools, Audacity, Reason.

- Applications and Software for Instrument Education: Applications and software for instrument education include topics such as instrument knowledge, instrument history, instrument training, instrument playing techniques. BrassNotes, Woodwind Fingering Chart, Drum School, Pianist Pro, Perfect Piano, Guitar Lessons are examples of software and applications in this area.

- Applications and Software for Choir/Singing: Applications and software in this cathegory include topics such as voice training, breathing use, vocal training, choir training, karaoke singing, lyrics. Song, Voice Jam, Harmony Voice, Singing Fingers, Choir and Organ, Erol Singer's Studio are examples of software and applications in this area.

- Applications and Software for Instrument for Music Performance: These kind of software and applications include music performance instruments such as chord instrument, metronome, effect pedal, amplifier, equalizer. Tuner Lite, N-Track Tuner, Metronome, Pro Metronome, AmpliTube, Equalizer are examples of software and applications in this area.

- Applications and Software for Listening/Watching Music: Applications and software for listening/watching music are video or audio player applications and software for listening and watching all types of music. Youtube, Spotify, Apple Music, Deezer, Vimeo, Dailymotion are examples of software and applications in this area.

\subsection{Study Group}

The study group of the research consists of 452 students in 1st, 2nd, 3rd and 4th grades in Music Education Department of Fine Arts Education in following universities:

Atatürk University Kazım Karabekir Faculty of Education,

Balıesir University Necatibey Faculty of Education,

Gazi University Gazi Faculty of Education,

Marmara University Atatürk Faculty of Education,

Niğde Ömer Halisdemir University Faculty of Education during the 2018-2019 academic year.

Table 1 shows the distribution of students according to the mentioned universities.

Table 1. Distribution of Students According to the Universities

\begin{tabular}{lll}
\hline University & f & $\mathbf{\%}$ \\
\hline Atatürk University & 73 & 16.2 \\
Balkesir University & 91 & 20.1 \\
Gazi University & 80 & 17.7 \\
Marmara University & 110 & 24.3 \\
Niğde Ömer Halisdemir University & 98 & 21.7 \\
\hline Total & $\mathbf{4 5 2}$ & $\mathbf{1 0 0}$
\end{tabular}

According to Table 1, it can be obtained that the university supplied the highest contribution on behalf of the respondents is Marmara University.

Demographic characteristics of the study group are given in Table 2 . 
Table 2. Demographic Characteristics of the Participants

\begin{tabular}{lcc}
\hline Gender & f & \% \\
\hline Female & 255 & 56.4 \\
Male & 197 & 43.6 \\
\hline Grade & f & $\%$ \\
\hline $\mathbf{1}^{\text {th }}$ Grade & 117 & 25.9 \\
$\mathbf{2}^{\text {th }}$ Grade & 109 & 24.1 \\
$\mathbf{3}^{\text {th }}$ Grade & 110 & 24.3 \\
$\mathbf{4}^{\text {th }}$ Grade & 116 & 25.7 \\
\hline
\end{tabular}

According to Table 2, it can be said that the majority of the participants were female and the average grade distribution was equal.

\subsection{Data Collection}

In order to collect data, a two-part questionnaire developed by the researcher was used. First part consists of 2 questions about the demographic information of the participants (Gender and Grade). The second part of the questionnaire consists of a total of 7 questions (Applications and software for music theory and hearing education - Applications and software for writing notes - Applications and software for recording/mixing stage - Applications and software for instrument education - Applications and software for choir/singing - Application and software containing instruments for music performance - Applications and software for listening/ watching music) regarding of the participants' awareness of applications and software (I have an idea / I have no idea), frequency of use (Never / Rarely / Sometimes / Often / Always) and purpose of use (Information acquisition / Professional development / Homework / Repeating courses / Accompanying studies / Entertainment / Rehearsal).

\subsection{Data Analysis}

In this study, percentage/frequency analysis was performed in order to determine music teacher candidates' awareness of applications and software, their frequency of use and purpose of use. Analysis methods such as Mann-Whitney U test, Kruskal Wallis test and Dunnett multiple comparison test which are among the non-parametric tests, were used to determine whether they differ according to gender and grade level variables. The analyses were performed with IBM SPSS Statistics 20 package program.

\section{Findings}

In this part of the research, firstly, the awareness of music teacher candidates about music applications and software, frequency of use and purpose of use were determined. Then, it was examined whether these results differed in terms of gender and grade variables.

\subsection{Findings Related to First Sub-problem}

Regarding the first sub-problem of the study, the awareness of music teacher candidates about music applications and software was examined and the data obtained are given in Table 3.

Table 3. Awareness of Applications and Software

\begin{tabular}{|c|c|c|c|}
\hline \multirow[t]{2}{*}{ Applications and Software for } & \multirow[t]{2}{*}{ Awareness } & \multicolumn{2}{|l|}{ Total } \\
\hline & & f & $\%$ \\
\hline \multirow{2}{*}{$\begin{array}{l}\text { Applications and software for music theory } \\
\text { and hearing education }\end{array}$} & I know & 207 & 45.8 \\
\hline & I don't know & 245 & 54.2 \\
\hline \multirow{2}{*}{ Applications and software for music notation } & I know & 391 & 86.5 \\
\hline & I don't know & 61 & 13.5 \\
\hline \multirow{2}{*}{$\begin{array}{l}\text { Applications and software for recording/ } \\
\text { mixing stage }\end{array}$} & I know & 288 & 63.7 \\
\hline & I don't know & 164 & 36.3 \\
\hline \multirow{2}{*}{$\begin{array}{l}\text { Applications and software for instrument } \\
\text { education }\end{array}$} & I know & 135 & 29.9 \\
\hline & I don't know & 317 & 70.1 \\
\hline \multirow{2}{*}{ Applications and software for choir/singing } & I know & 140 & 31.0 \\
\hline & I don't know & 312 & 69.0 \\
\hline \multirow{2}{*}{$\begin{array}{l}\text { Application and software containing } \\
\text { instruments for music performance }\end{array}$} & I know & 384 & 85.0 \\
\hline & I don't know & 68 & 15.0 \\
\hline \multirow{2}{*}{$\begin{array}{l}\text { Applications and software for listening/ } \\
\text { watching music }\end{array}$} & I know & 307 & 67.9 \\
\hline & I don't know & 145 & 32.1 \\
\hline
\end{tabular}

When Table 3 is examined, it is seen that music teacher candidates who are aware of the existence of applications for music notation, applications containing instruments for music performance, applications for listening/watching music, and applications for recording/mixing stage are higher than those who are not aware. It is observed that the number of 
those who are not aware of the applications of instrument education, applications of choir/singing and applications of music theory and hearing education are higher than those who are aware of.

The participants were asked the names of the most frequently known applications and software. Accordingly, the most frequently known applications and software for music theory and hearing education were Ear Master, Perfect Ear, Toria; the most frequently applications and software for writing notes were Finale, Sibelius, Muse Score; the most frequently known applications and software for recording / mixing stage were Garage Band, Cubase, Logic; the most frequently known applications and software for instrument education were Guitar Pro, Piano; the most frequently known applications and software for choir / singing were Simule, Vocalive, Acapella; the most frequently known applications and software tools for music performance were N Track Tuner, Metronome; the most frequently known applications and software for listening / watching music were You Tube, Spotify, Apple Music.

According to the results of Mann-Whitney U Test on whether music teacher candidates' awareness of applications and software differed by gender, it was found that the applications of music theory and hearing education, music notation applications, instrument education applications, applications related to music performance instruments and applications for listening and watching music did not differ according to gender in terms of awareness (P>.05). It was determined that the awareness level for the applications for recording/mixing stage and choir/singing applications differed according to gender. The results are given in Table 4.

Table 4. Mann-Whitney U Test results on whether the status of awareness varies according to gender

\begin{tabular}{|c|c|c|c|c|c|c|}
\hline & Gender & $\mathbf{N}$ & $\begin{array}{l}\text { Mean } \\
\text { Rank } \\
\end{array}$ & $\begin{array}{ll}\text { Sum of } \\
\text { Ranks }\end{array}$ & $\mathbf{U}$ & $p$ \\
\hline \multirow{2}{*}{$\begin{array}{l}\text { Applications and software for recording/ mixing } \\
\text { stage }\end{array}$} & Female & 255 & 214.55 & $54,711.50$ & \multirow[t]{2}{*}{$22,071.50$} & \multirow[t]{2}{*}{.008} \\
\hline & Male & 197 & 241.96 & 47666,50 & & \\
\hline \multirow[t]{2}{*}{ Applications and software for choir/singing } & Female & 255 & 237.15 & $60,473.50$ & \multirow[t]{2}{*}{$22,401.50$} & \multirow[t]{2}{*}{.014} \\
\hline & Male & 197 & 212.71 & $41,904.50$ & & \\
\hline
\end{tabular}

According to Table 4, it was found that the awareness in recording/mixing stage application and choir/singing applications differed according to gender $(\mathrm{p}<.05)$. When the average of the rankings is taken into consideration, it is seen that the male participants hear the applications for recording/mixing stage and the female participants hear the applications for choir/singing more.

According to the results of Kruskal Wallis Test on whether the music teacher candidates awareness of applications and software differed according to grade, applications for music theory and hearing education, applications for recording/mixing stage, applications for choir/singing, applications that include instruments for music performance, and applications for listening/watching music did not differ according to grade ( $\mathrm{P}>05$ ). As for the music notation applications and instrument education applications, it was found that awareness levels differed by grade. The results are given in Table 5.

Table 5. The results of Kruskal Wallis Test on whether the status of awareness differs according to the grade variable

\begin{tabular}{llllllll}
\hline & Grade & $\overline{\mathbf{x}}$ & $\mathbf{N}$ & Mean Rank & $\mathbf{d f}$ & $\boldsymbol{x}^{\mathbf{2}}$ & $\boldsymbol{p}$ \\
\hline Applications and software for writing & $1^{\text {th }}$ Grade & 1.73 & 117 & 195.19 & 3 & 27.599 & .000 \\
& $2^{\text {th }}$ Grade & 1.88 & 109 & 230.05 & & & \\
& $3^{\text {th }}$ Grade & 1.92 & 110 & 238.51 & & & \\
& $4^{\text {th }}$ Grade & 1.94 & 116 & 243.36 & & & \\
\hline Applications and software for & $1^{\text {th }}$ Grade & 1.25 & 117 & 215.02 & 3 & 14.688 & .002 \\
instrument education & $2^{\text {th }}$ Grade & 1.19 & 109 & 202.54 & & & \\
& $3^{\text {th }}$ Grade & 1.35 & 110 & 237.07 & & & \\
& $4^{\text {th }}$ Grade & 1.41 & 116 & 250.57 & & & \\
\hline
\end{tabular}

According to Table 5, it was found that the awareness in music notation applications and instrument education applications differed by grade ( $\mathrm{p}<.05)$. As a result of the Dunnett multiple comparison test conducted to determine which groups caused the difference, it was seen that the difference in the awareness of writing applications was due to 1 st grade and the number of people who did not hear was higher than the other grades. It was found that the difference in the applications related to instrument education was due to the 2 nd grade and the number of those who did not hear was higher than the 4 th grade students.

\subsection{Findings Related to Second Sub-problem}

Regarding the second sub-problem of the study, music teacher candidates' frequency of using music applications and software was examined and the data obtained are given in Table 6. 
Table 6. Music teacher candidates' frequency of using music applications and software

\begin{tabular}{|c|c|c|c|c|c|c|c|}
\hline Applications and Software & & Never & Rarely & Sometimes & Often & Always & $\overline{\mathbf{x}}$ \\
\hline \multirow{2}{*}{$\begin{array}{l}\text { Applications and software for music theory and } \\
\text { hearing education }\end{array}$} & f & 273 & 71 & 61 & 38 & 9 & 1.76 \\
\hline & $\%$ & 60.4 & 15.7 & 13.5 & 8.4 & 2.0 & \\
\hline \multirow{2}{*}{ Applications and software for writing notes } & $\mathbf{f}$ & 105 & 129 & 152 & 59 & 7 & 2.41 \\
\hline & $\%$ & 23.2 & 28.5 & 33.6 & 13.1 & 1.5 & \\
\hline \multirow{2}{*}{$\begin{array}{l}\text { Applications and software for recording/ mixing } \\
\text { stage }\end{array}$} & $\mathbf{f}$ & 220 & 93 & 82 & 45 & 12 & 1.97 \\
\hline & $\%$ & 48.7 & 20.6 & 18.1 & 10.0 & 2.7 & \\
\hline \multirow{2}{*}{$\begin{array}{l}\text { Applications and software for instrument } \\
\text { education }\end{array}$} & $\mathbf{f}$ & 335 & 35 & 48 & 26 & 8 & 1.53 \\
\hline & $\%$ & 74.1 & 7.7 & 10.6 & 5.8 & 1.8 & \\
\hline \multirow{2}{*}{ Applications and software for choir/singing } & $\mathbf{f}$ & 341 & 42 & 43 & 24 & 2 & 1.46 \\
\hline & $\%$ & 75.4 & 9.3 & 9.5 & 5.3 & 0.4 & \\
\hline \multirow{2}{*}{$\begin{array}{l}\text { Application and software containing instruments } \\
\text { for music performance }\end{array}$} & $\mathbf{f}$ & 79 & 26 & 57 & 162 & 128 & 3.52 \\
\hline & $\%$ & 17.5 & 5.8 & 12.6 & 35.8 & 28.3 & \\
\hline \multirow{2}{*}{$\begin{array}{l}\text { Applications and software for listening/ watching } \\
\text { music }\end{array}$} & $\mathbf{f}$ & 152 & 25 & 30 & 93 & 152 & 3.15 \\
\hline & $\%$ & 33.6 & 5.5 & 6.6 & 20.6 & 33.6 & \\
\hline
\end{tabular}

According to Table 6, it was found that the most commonly used applications were the applications that include instruments for music performance and applications for listening/watching music. It was seen that applications for choir/singing, applications for instrument education, applications for music theory and hearing education, and applications for recording/mixing stage are rarely used and applications for music notation are rarely or sometimes used. According to this result, which is parallel to the first sub-problem, it is understood that the applications that are known more are used a lot.

According to the results of Mann-Whitney U Test, whether music teacher candidates' frequency of using music applications and software differs according to gender, it was found that the awareness in applications for music notation, applications for instrument education and applications containing instruments for music performance did not differ according to gender ( $\mathrm{p}>.05)$. It was found that the awareness in applications for music theory and hearing education, applications for recording/mixing stage, applications for choir/singing and applications for listening/watching music differed according to gender. The results are given in Table 7.

Table 7. Mann-Whitney U Test results on whether the frequency of use differs according to gender variable

\begin{tabular}{|c|c|c|c|c|c|c|c|}
\hline & Gender & $\overline{\mathbf{x}}$ & $\mathbf{N}$ & $\begin{array}{l}\text { Mean } \\
\text { Rank }\end{array}$ & $\begin{array}{l}\text { Sum of } \\
\text { Ranks }\end{array}$ & $\mathbf{U}$ & $p$ \\
\hline \multirow{2}{*}{$\begin{array}{l}\text { Applications and software for music } \\
\text { theory and hearing education }\end{array}$} & Female & 1.65 & 255 & 217.02 & $55,341.00$ & \multirow[t]{2}{*}{$22,701.00$} & \multirow[t]{2}{*}{.046} \\
\hline & Male & 1.89 & 197 & 238.77 & $47,037.00$ & & \\
\hline \multirow{2}{*}{$\begin{array}{l}\text { Applications and software for recording/ } \\
\text { mixing stage }\end{array}$} & Female & 1.76 & 255 & 205.03 & $52,282.50$ & \multirow[t]{2}{*}{$19,642.50$} & \multirow[t]{2}{*}{.000} \\
\hline & Male & 2.25 & 197 & 254.29 & $50,095.50$ & & \\
\hline \multirow{2}{*}{$\begin{array}{l}\text { Applications and software for } \\
\text { choir/singing }\end{array}$} & Female & 1.58 & 255 & 240.59 & $61,350.00$ & \multirow[t]{2}{*}{$21,525.00$} & \multirow[t]{2}{*}{.001} \\
\hline & Male & 1.30 & 197 & 208.26 & $41,028.00$ & & \\
\hline \multirow{2}{*}{$\begin{array}{l}\text { Applications and software for listening/ } \\
\text { watching music }\end{array}$} & Female & 3.01 & 255 & 216.19 & $55,129.50$ & \multirow[t]{2}{*}{$22,489.50$} & \multirow[t]{2}{*}{.046} \\
\hline & Male & 3.34 & 197 & 239.84 & $47,248.50$ & & \\
\hline
\end{tabular}

According to Table 7, it was found that the awareness in music applications for music theory and hearing education, applications for recording/mixing stage, applications for choir/singing and applications for listening/watching music differed according to gender $(\mathrm{p}<.05)$. When the average of the table in Table 7 is examined, it is seen that male participants used music theory and hearing education applications, recording/mixing stage applications and listening to music/watching applications more than female participants, whereas the choir/singing applications are used by female participants more than the male participants.

According to the results of Kruskal Wallis Test on whether music teacher candidates' frequency of using music applications and software differed according to grade, it was found that music theory and hearing education applications, recording/mixing stage applications, choir/singing applications, applications that include instruments for music performance, and applications for listening/watching music did not differ according to grade $(\mathrm{P}>.05)$. It was determined that the frequency of use differed according to grade in applications for music notation and applications for instrument education. The results are given in Table 8. 
Table 8. Kruskal Wallis Test results on whether the frequency of use differs according to grade variable

\begin{tabular}{llllllll}
\hline & Grade & $\overline{\mathbf{x}}$ & $\mathbf{N}$ & $\begin{array}{l}\text { Mean } \\
\text { Rank }\end{array}$ & $\mathbf{d f}$ & $\boldsymbol{x}^{\mathbf{2}}$ & $\boldsymbol{p}$ \\
\hline Applications and software for & $1^{\text {th }}$ Grade & 2.13 & 117 & 192.12 & 3 & 13,262 & .004 \\
writing notes & $2^{\text {th }}$ Grade & 2.42 & 109 & 226.72 & & & \\
& $3^{\text {th }}$ Grade & 2.55 & 110 & 243.78 & & & \\
& $4^{\text {th }}$ Grade & 2.55 & 116 & 244.58 & & & .039 \\
Applications and software for & $1^{\text {th }}$ Grade & 1.52 & 117 & 223.35 & 3 & 8,344 & \\
instrument education & $2^{\text {th }}$ Grade & 1.36 & 109 & 205.81 & & & \\
& $3^{\text {th }}$ Grade & 1.58 & 110 & 232.90 & & & \\
& $4^{\text {th }}$ Grade & 1.66 & 116 & 243.06 & & & \\
\hline
\end{tabular}

According to Table 8, it was found that the awareness in applications for music notation and the applications for instrument education differed according to the grade $(\mathrm{p}<.05)$. As a result of the Dunnett multiple comparison test, which was conducted to determine which groups caused the difference, it was seen that the difference in the frequency of use in music notation applications was due to 1st grade and it was used less than the other grades. It was found that the difference in the applications for instrument education was due to the 2 nd grade and it was used less than the 4th grade especially.

\subsection{Findings Related to Third Sub-problem}

Regarding the third sub-problem of the research, the purpose of the music teacher candidates to use the music applications and software were examined and the data obtained are given in Table 9.

Table 9. Music teacher candidates' purpose to use music applications and software

\begin{tabular}{|c|c|c|c|c|c|c|c|c|c|}
\hline & & 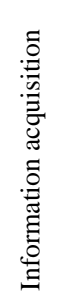 & 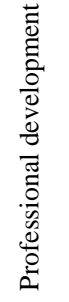 & $\begin{array}{l}\text { U. } \\
\vdots \\
0 \\
0 \\
0 \\
0\end{array}$ & 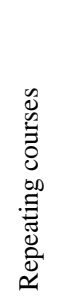 & 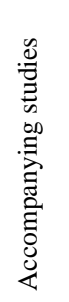 & 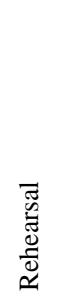 & 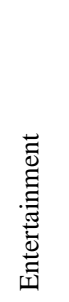 & 赵 \\
\hline \multirow{2}{*}{ Applications and software for music theory and hearing education } & f & 56 & 92 & 73 & 33 & 33 & 14 & 36 & 337 \\
\hline & $\%$ & 16.6 & 27.3 & 21.7 & 9.8 & 9.8 & 4.2 & 10.7 & 100 \\
\hline \multirow[t]{2}{*}{ Applications and software for writing notes } & f & 86 & 144 & 204 & 38 & 85 & 18 & 57 & 632 \\
\hline & $\%$ & 13.6 & 22.8 & 32.3 & 6.0 & 13.4 & 2.8 & 9.0 & 100 \\
\hline \multirow[t]{2}{*}{ Applications and software for recording/ mixing stage } & f & 51 & 84 & 48 & 16 & 48 & 34 & 110 & 388 \\
\hline & $\%$ & 13.1 & 21.6 & 12.4 & 4.1 & 12.4 & 8.0 & 28.4 & 100 \\
\hline \multirow[t]{2}{*}{ Applications and software for instrument education } & f & 26 & 45 & 28 & 15 & 34 & 15 & 24 & 187 \\
\hline & $\%$ & 13.9 & 24.1 & 15.0 & 8.0 & 18.2 & 8.0 & 12.8 & 100 \\
\hline \multirow[t]{2}{*}{ Applications and software for choir/singing } & f & 24 & 25 & 19 & 12 & 17 & 49 & 13 & 159 \\
\hline & $\%$ & 15.1 & 15.7 & 11.9 & 7.5 & 10.7 & 8.2 & 30.8 & 100 \\
\hline \multirow[t]{2}{*}{ Application and software containing instruments for music performance } & f & 62 & 158 & 118 & 61 & 65 & 46 & 115 & 625 \\
\hline & $\%$ & 9.9 & 25.3 & 18.9 & 9.8 & 10.4 & 18.4 & 7.4 & 100 \\
\hline \multirow[t]{2}{*}{ Applications and software for listening/ watching music } & f & 127 & 124 & 75 & 52 & 59 & 224 & 53 & 714 \\
\hline & $\%$ & 17.8 & 17.4 & 10.5 & 7.3 & 8.3 & 7.4 & 31.4 & 100 \\
\hline
\end{tabular}

When Table 9 is examined, it is seen that the applications that are most frequently answered are applications for listening/watching music, applications for writing notes and instruments for music performance. The least amount of answers was given to the choir/singing applications. According to Table 13; applications for music theory and hearing education, applications for instrument education and applications including instruments for music performance were mostly used for professional development purposes; music notation applications were mostly used for homework; listening/watching music applications, recording/mixing stage applications and choir/singing applications were mostly used for entertainment purposes.

\section{Conclusion and Discussion}

According to the results of the research, it was seen that the amount of music teacher candidates who were aware of the existence of applications for music notation, applications containing instruments for music performance, applications for listening/watching music and applications for recording/mixing stage was quite high compared to those who were 
not aware. It was seen that the number of those who were not aware of the applications of instrument education, applications of choir/singing, and the applications of music theory and hearing education were higher than those who were aware. In this context, it can be said that the music teacher candidates have less idea about the applications and software especially for the performance aspect of the music. In this case, it is thought that the music teacher candidates use traditional methods in the performance fields of music such as playing and singing and do not use the technology that much in this field.

According to the results of the study, it was found that male participants have an idea about the applications for recording/mixing stage and female participants have an idea about the applications for choir/singing more. It was found that the first grade students hear the applications for music notation less than the other grades and the second grade students have an idea about the applications for instrument training less.

When considered in terms of frequency of use, it was seen that the most commonly used applications were applications that include instruments for music performance and applications for listening/watching music. Researches conducted by Küçükayvaz (2017), Özçelik Herdem (2017) and Parasız (2018) also support this result. In these studies, it was stated that especially the applications for listening / watching music were used by students and it was an effective music education tool. It was seen that applications for choir/singing, applications for instrument education, applications for music theory and hearing education, and applications for recording/mixing stage were rarely used. In particular, it was seen that the applications for recording / mixing stage were known more but used less. According to Purves (2018), integrating voice recording into our music education programs can help create a rich, student-centered environment for our students. In this respect, it is considered that music teacher candidates should be provided with trainings that will enable them to use the applications related to recording/mixing $\mathrm{s}$

tage in music education. Although music notation applications are among the most popular applications, they are rarely or sometimes used. According to this result, which is parallel to the first sub-problem, it is understood that the applications that are known more are used a lot. In this context, it can be said that the candidates of music teachers use the applications and software less especially for the performance aspect of the music. In the study conducted by Özçelik Herdem (2017), it was found that music students only use technology for watching/listening, and they use music notation, accompaniment and recording programs inadequately. Although most applications have mobile versions, professional applications are still much more expensive, which may be the reason for the lack of use. Kılıç (2017) states that computer software related to music is known by teachers but cannot be used in the classroom because of economic opportunities and lack of music classes.

It was observed that the music theory and hearing education applications, recording/mixing stage applications and applications for listening / watching music were used more by male participants than female participants. On the other hand, it was found that female participants used the choir / singing practices more than male participants. It has been observed that the usage level increases with grade level in music notation applications. It was found that the 2 nd grade students used the instrument education practices less than the other classes.

According to the results obtained from the research, applications for music theory and hearing education, applications for instrument education and applications containing instruments for music performance were mostly used for professional development purposes. Considering that these practices involve more professional skills, the result is meaningful. It was found that applications for music notation were mostly used for homework. Music notation programs are an important tool for anyone interested in music. These applications, which provide a more visual product especially in terms of unity and order of writing, also free the person from a huge workload. In this respect, it is seen as a natural result that music teacher candidates use these applications and software for homework. Applications for listening/watching music, recording/mixing stage and chorus/singing are mostly used for entertainment purposes. Especially when applications for listening and watching music and singing are examined, it is seen that these are simple and fun applications that appeal to everyone.

The results of the research showed that the music teachers candidates did not know and use their music applications and software adequately. Today's mobile music applications are aimed at everyone who tries to learn music, making it easier to access difficult musical elements (such as acquiring instruments, learning, recording, knowing notes, etc.). Music technologies allow individuals to create music that they think and design on their own, without any instrument skills, by ignoring criticism. Another important feature of music applications is that it makes complicated elements of music easier to understand by visualising them. In this direction, it is thought that music teacher candidates should be given training in order to better know their music applications and software and to use these applications with the accurate methods and techniques. 


\section{References}

Aksoy, H. H. (2003). Eğitim kurumlarında teknoloji kullanımı ve etkilerine ilişkin bir çözümleme. Eğitim Bilim Toplum Dergisi, 1(4), 4-23.

Axford, E. C. (2015). Music Apps for Musicians and Music Teachers. New York: Rowman \& Littlefield

Brown, A. R. (2012). Computers in music education: Amplifying musicality. New York: Routledge. https://doi.org/10.4324/9780203942949

Kılıç, A. (2017). İlköğretim ve ortaöğretim müzik öğretmenlerinin öğretim teknolojileri ve materyallerine yönelik farkındalık düzeyleri. In Ç. Adar (Ed.), VIII. Uluslararası Hisarlı Ahmet Sempozyumu (38-55). Kütahya: Dumlupinar.

Küçükayvaz, İ. E. (2017). Güzel sanatlar liseleri piyano eğitimci ve öğrencilerin müzik dinleme ve paylaşma araçları. In Ç. Adar (Ed.), VIII. Uluslararası Hisarlı Ahmet Sempozyumu (252-265). Kütahya: Dumlupınar.

McCord, K. (2001). Music Software for Special Needs: Music educators faced with adapting their instruction for children with special needs can find effective tools in computer software. Music Educators Journal, 87(4), 30-64. https://doi.org/10.2307/3399722

Özçelik, H. D. (2017). Keman eğitiminde teknolojinin kullanılmasına yönelik yaklaşımların değerlendirilmesi (Müzik öğretmenliği programı). In Ç. Adar (Ed.), VIII. Uluslararası Hisarlı Ahmet Sempozyumu (168-169). Kütahya: Dumlupınar.

Parasız, G. (2018). The Use of Music Technologies in Field Education Courses and Daily Lives of Music Education Department Students (Sample of Atatürk University). Universal Journal of Educational Research, 6(5), 1005-1014. https://doi.org/10.13189/ujer.2018.060521

Peters, G. D. (1992). Music Software and Emerging Technology: G. David Peters outlines the history of music software and hardware and explores the new developments and benefits of the emerging software for use in the classroom. Music Educators Journal, 79(3), 22-63. https://doi.org/10.2307/3398478

Purves, R. (2018). Technology And The Educator. In Gary E. McPherson \& Graham F. Welch (Ed.), Creativities, Technologies, And Media In Music Learning And Teaching (p. 143-161). New York: Oxford University Press.

Reese, S., \& Rimington, J. (2000). Music Technology In Illinois Public Schools. Applications of Research in Music Education, 18(2), 27-32. https://doi.org/10.1177/875512330001800206

Roblyer, M. D., \& Edwards, J. (2000). Integrating educational technology into teaching ( ${ }^{\text {nd }}$ Ed.). Columbus, Ohio: Prentice Hall/Merrill.

Toro, M. (2018). Current Trends and Future Research Directions for Interactive Music. arXiv preprint arXiv:1810.04276.

Turan, Z., Yılmaz, R. M., Durdu, L., \& Göktaş, Y. (2016). Öğretim Teknolojilerinin Tarihsel Gelişimi. In Çağıltay, K., \& Göktaş, Y. (Eds.), Ögretim teknolojilerinin temelleri: teoriler, araşstırmalar, eğilimler in (25-40), 2th edition, Ankara: Pegem Akademi.

Usta, E., \& Korkmaz, Ö. (2010). Öğretmen adaylarının bilgisayar yeterlikleri ve teknoloji kullanımına ilişkin algıları ile öğretmenlik mesleğine yönelik tutumları. Uluslararası İnsan Bilimleri Dergisi, 7(1), 1335-1349.

Yükseltürk, E., \& Top, E. (2016). Web 2.0 Teknolojilerinin Öğretmen Eğitiminde Kullanımı. Çağıltay, In K., \& Göktaş, Y. (Eds.), Öğretim teknolojilerinin temelleri: teoriler, araştırmalar, eğilimler in (555-570), 2th edition, Ankara: Pegem Akademi.

\section{Copyrights}

Copyright for this article is retained by the author(s), with first publication rights granted to the journal.

This is an open-access article distributed under the terms and conditions of the Creative Commons Attribution license which permits unrestricted use, distribution, and reproduction in any medium, provided the original work is properly cited. 